\title{
Greed from the Educational Point of View of Islam
}

\author{
Sayyed Hossain Vaezi* \\ Corresponding Author: PhD, Assistant Professor, Department of Theology, \\ Islamic Azad University Isfahan (Khorasgan) Branch, Isfahan, Iran \\ sh.vaezi@khuisf.ac.ir
}

\author{
Akbar Rahimi-Kelishadi \\ MA Student of the History and Philosophy of Education, \\ Islamic Azad University Isfahan (Khorasgan) Branch, Isfahan, Iran
}

\section{Doi:10.5901/mjss.2015.v6n2s1p147}

Abstract

This study aimed to study the role of greed from the point of view of Islamic education using a qualitative method and content analysis. Data collected by library resources showed the greed is an innate trait in humans causing a person to desire to possess a God's blessing entirely, and if others use this blessing, that person will become sad. When there is no greed trait in a man, the mental health is affected and s/he will suffer from mental instability. Therefore, this attribute accompanied with Islamic training method should be used to guide persons properly. It has been divided into two parts as the praised and the reviled by ethics scholars. The praised part leads to helping, fairly competing to perform necessities and charity, and eliminating unpleasant features; the reviled part is the root of many difficulties and the destruction of human benefits. This trait must be fought against and controlled; contentment and generosity are the cures for the reviled part.

Keywords: Greed, education, nature, caliph of God.

\section{Introduction}

\subsection{Definitions}

Greed means the intensive desire for something (Ragheb Isfahani, 1971).

Education means training, nurturing, teaching others ethics and politeness (Amid, 1951). Innate means creation, innovation and to split (Ragheb Isfahani, 1971) as well creation of every attribute that a creature owns from the beginning of its creation (DehKhoda, 1958).

Caliph of God means to be the successor of God, it is a rank which a disciple obtains after different stages of purifying his conscience and soul and rejecting and preventing attributes and businesses of mankind. Because of these stages he is supposed to guide others ( Ja'far Sajjadi, 1996; Goharin, 1988).

\section{Discussion}

Research methodology which is used in present article is qualitative and data gathering is made through library research. Due to the lack of statistic data and non-measurable nature of the topic, the quantitative research was not possible.

\subsection{Training in the universe}

If God is all the creatures' "rab" which means "trainer", all the creatures should have the ability to be trained. In all the aspects of the universe the instruction is available, although it is not comprehended by some people (Holy Quran). " Tell them do you look for a trainer except God while He is the trainer of everything"( Al An'aam, 164). According to this verse of Holy Quran, training is being done in every aspect of the universe and everything is being trained and guided toward perfection and it is done by the will of God and nothing can interfere in it and there is no partner for God.

Historically, greed is the intrinsic characteristic of human being. Therefore, we may find it in the conscience of all humans and it is constant in all eras. Due to its nature, greed is not educable but it is controllable and a proper education is beneficial to put it in a positive direction. 
With this in mind every creature is being trained and its capacities are getting matured and some new potentialities are created in them. They reach to perfection and prerequisites for ideal perfection, and all parts of the universe are moving in the same route. This movement is called "divine tradition" and it is accomplished by the will of God.

\subsection{The characteristic of the spreading of training in the universe:}

a. Being rule governed: Training is rule governed in all aspects. By rule it is meant the tradition of God which is available all over the universe.

b. The rule is done by God's will and cannot be disobeyed.

c. By divine inspiration all the phenomena know these traditions and obey them, so inspiration is the medium between God and phenomena in realizing rules and it is called "guidance". Verses which are about praising God are evidence to this.

d. The perfection of phenomena is due to obeying this divine rules ( Vaseghi, 2002, pp:27- 28).

\section{Hypothesis}

Greed is an innate trait and is necessity of life and if it is trained correctly, some of the problems of humans will be solved and if it is not, it will cause mankind to face a lot of problems and it will prevent humans of the main goal of creating humans which is self-recognition and obeying God's traditions.

The main purpose of this article is to review "Greed" and its didactic role from Islamic point of view. The secondary purpose is to scrutinize in the causes of the greed formation in human personality and its personal and social effects as well as its control.

\subsection{Proving:}

It is stated in Holy Quran:" When we give man affluence (because of arrogance and negligence), he forgets us and when he faces an evil, he gets disappointed and ashamed. You the prophet tell them: every human behaves according to his nature. God (your trainer is) is aware of those who are guided"(Al Asra, 83-84). These verses are evidence to two different states of human:

\subsubsection{The elementary form of human}

When the human is given affluence and blessing, he becomes arrogant and selfish and forgets God and on the other hand when he faces a problem and poverty, he becomes disappointed and ashamed.

\subsubsection{Moving toward God}

Some are guided toward God and their route is clear and toward the right end. By nature is meant the elementary innate of human without being trained and without any change in humans capacities; since human is a creature with the ability to improve and to achieve perfection. So by the primitive nature it is meant the raw capacity and ability which may cause human to be disappointed and unbeliever in the case it is not trained and if it is trained the human will get to the highest rank of humanity and glory. In the human's nature there is a truth which becomes real by training and mortification. Human is a complicated creature and is not able to achieve what is not located in his nature. The human which is mentioned in the above verse is not his holy nature but the average and common human with ordinary thought and conditions and getting unbeliever and disappointed originated from this nature. Those who are guided by divine guidance get pure from this kind of nature but not from absolute nature (Tabatabayee, 1984). In fact human is an impatient and greedy creature. When he faces a problem, he cries in disappointment and when he is awarded a benefit he confines it to himself excessively. Except those who pray continuously, help the poor, believe in resurrection day and are afraid of it (Alma'aarej, 19-38).

According to these verses the human is impatient and uneasy. In difficulties cries out but in the time of welfare and good luck he forgets others and doesn't share it with others but the real believers are different. They pray God, fear God, believe in God and resurrection day, are truthfulness and trustworthy and avoid adultery and anything unpleasant by God. According to these verses the people who pray do not have the crying, impatient and greedy nature. The nature of praying should be activated to cause the divine nature appear. Therefore, creating human with a greedy nature is one of 
the positions of the human and it is not the main and final nature of human. These verses describe the general and usual position of human and it is different from divine and rational nature of him (Hosseini Tehrani, p:183-176).

Imam Ali has said this about greed: "Greed, jealous and fear are innates which are originated from suspicion to God".( Reyshahri, 1982, volume 2, p:588) Imam Ali has advised Maalik Ashtar not to consult cowards, jealous and greedy people; besides he has stated that Greed, jealous and fear are originated from suspicion to God (Nahj-al-Balaghe, 2000, P:571).

\subsection{Being innate and the formation of greed:}

Muslim scientists believe that the conscience of human is not like a white page that different experiences would make some traces on it but there is a hidden power which makes some reactions against some things. By God's nature it is meant what God has created people according to it and it is a situation which human is created on its basis.

Here are some speeches of some scientists:" Divine innate is of the graces God has awarded just to human and if it is awarded to other creatures it imperfect or they don't enjoy it so much." (Khomeini, 1967, p:180). Human owns a specific nature which guides him toward specific tradition and a clear route"( Tabatabyee, volume 16, p:178)." In humans nature there is a willing toward unification and he knows God" ( Shoja'ee, 2007, Mesbah Yazdi, p:244).

Plato believes that every baby has a special nature with which it is born and is aware of it, but Holy Quran does not confirm it; according to Holy Quran these abilities exist in every person and when a child is able to imagine them, confirms them according to its nature, and it means that it does not require teaching and reasoning (Motahhari, 1980, p:53).

In Holy Quran has been stated that:" Reject every other religion and come toward the belief in one God- what God has created innately to be-. What God has created is always the same. This is the right religion but most people don't know it" ( Alroom, 30).

\subsection{The educational role of Islam in Controlling Greed and its Effects:}

Virtue controls human and prevents him from committing sins; in the same way good education is efficient in creating virtue and preventing human from being greedy:

Human can improve many stages until he gets to a stage of divinity. A revolution which starts from nature and results to a stage in which he can't see anybody except God. Human is able to revolve so and create all the intellectuality by means of good education and reaches to a rank which is higher than angels (Khomeini, 2008, Volume 7, p: 283).

By using the guidance of Islam and Holy Quran it is concluded that human has the capacity to be educated. The scientists who have lived in the era before Islam, like Plato confirm this fact. Plato has defined education as creating good habits and very elementary feelings and believes it is resulted from the environment, the educator, and the activation of his talents. Aristotle and Plato believe that moral education is linked to social and political education and personal education is connected to social education ( Kardan et all, 2010).

Human is the excellent creature of God and shows the power of God. Human has the capability to obtain all the divine traits and to become Caliph of God and it is done only by means of a real and good education. Human is innately spiritual and heavenly, during some stages he delegate to the lowest point and by education he is able to obtain the highest ranks ( Delshad Tehrani, 2008. P: 17).

So according to religious guidance, human is able to control the greed and educate it and consider mundane world as well but not to allow the materialistic world to involve him so that he forgets spiritual virtues.

\section{The Effects of Greed on Human}

Imam Ali has said" The result of greed kill wisdom."( Rasooli Mahallati, 2006, Volume:2, p:26) Those who are not greedy have controlled their greed destructive effects and have established a calm and relaxed life, because their wisdom has guided them toward real requirements and has prevented them from what is not a real need. Therefore they are not encouraged to be greedy. Being excessively involved in the mundane world and worldly life and getting extremely busy by them are resulted from ignoring God and the mercy and kindness of God heartily and in action. Because of this people are disconnected from God. So the tranquility and trust of the soul disappear and they are replaced by stress and agitation ( Khomeini,1992, p:217). 


\subsection{Some Personal Effects of Greed}

1. Greed causes human to suffer forever.

2. The greedy never satisfy even when they own all the world's wealth.

3. The greedy live like the poor, die like the poor but they are evaluated and calculated like the rich in the other world.

4. Greedy people accelerate toward the wealth and they are so busy collecting money that they never notice the hazards of it so they have a risky and dangerous life.

5. A greedy person engages himself in mundane world and loses his safe life.

6. A greedy person ignores his social rank and does everything to obtain money so damages his prestige.

7. It causes man to commit different sins like lying, treachery, oppression, and usurpation. Since without them he cannot obtain what he wants.

8. Greed causes man to forget God. Others don't respect him because of his greed, and he will suffer.

9. He is the guard of what has collected but his heirs will use it.

10. The first sin man (Adam and Eve) committed was greed and it made them leave heaven.

11. Those who suspect in God become greedy and greed will intensify this suspicion (Makarem Shirazi, 2006).

12. Greed causes man to be dishonest while being consulted because he will support what is beneficial for him not what is true.

13. Blasphemy is resulted from greed since it causes suspicion to God and refusing that God is provider.

14. Greed makes man forget God and it is the biggest sin in his life since every sin man commits is because of forgetting God, if not he would repent it.

15. It causes man to be disappointed in God. In holy Quran getting disappointed in God is a big sin. God has old sinners not to get disappointed in God's mercy since unbelievers do this.

16. Greedy people deprive themselves of the most of the affluences of the other world.

17. A greedy man thinks by collecting money guarantee his future but he will suffer from poverty since the money he has collected has no blessing.

18. Adversity is one of the bad results of greed.

19. Not only greed is a bad trait, it brings other bad traits with it.

20. Greed wastes man's time collecting money and engaging in mundane affairs. He has no time to stop and think about what has done. The more he collects money the more he is involved and busy (Zarnagar and Valazadeh. 2012, p:1-3).

21. A greedy man is always worried about what he has collected.

22. A greedy man's family, relatives and acquaintances disrespect him because of this trait.

23. Greedy people are impatient and they always complaint facing a small problem.

24. People don't trust greedy people.

25. Being interested in mundane world causes sins and greed is one of the symbols of being interested in the world.

Considering the bad consequences of greed, every wise person realizes how unwelcome and bad greed is. Trying to get what he doesn't need is called greed and it is disagreeable. Islam, the holy prophet and Imams have blamed greed. Being unsatisfied, collecting such a wealth which can't be spent even in a life time is a trait which eradicate people's peace and relax (ya'ghoobi,2009).

Imam Sadegh has stated:" Greed people are deprived of two things: 1.They lack contentment so they lose their peace.2. They don't have satisfaction, so they lack certainty (Mohammadi Reyshahri, 1983, p:578).

Being interested in worldly life is originated from interest in perfection. But sometimes man makes mistakes in his path and the beauty of this world and sensuality effect his wisdom (Tehrani, 2013).

\subsection{The effects of Greed on the Society}

When a society is infected by greed, competition and struggle replaces safety and justice. So ethics and spirituality disappear. The greedy peoples' activities cause some bad fortunes and bad happenings in society. They ignore justice and do everything to earn what they want and create intensive economic calamities in the society.( Moosavi Lari, 2012, p:5). Greed is the source of wars, crimes, plunders and disregarding human rights and ethics (Makarem Shirazi, 2006).

According to what was mentioned above these are some social effects of greed:

1. Victimizing ethics and humanistic virtues. 
2. Replacing social life by quarreling and struggling.

3. Making human leave the heaven.

4. Causing different crimes and wars.

5. Creating public poverty and economic calamities.

6. Disappearing justice and social safety.

When greed becomes prevalent in a society, every member of that society tries to make others serve him. Ethics, public safety and trust disappear.

\section{Cures for Greed}

1. Thinking about the effects and results of greed: When man reflects in the effects of greed by using reasoning and wisdom only follows good greed. Imam Sadegh has said :" Thinking is like a mirror that shows every good thing, compensates every bad thing, guides the heart toward the right path, supports ethics, helps to have a good life in the other world, informs you about the destiny and increases the knowledge"( Vaseghi Raad, 2003, p:113).

2. Reinforcing religious beliefs: By means of reinforcing religious belief and great people of religion, everyone uses moderate amount of greed and avoids unpleasant greed.

3. Obtaining certainty: A believer man believes in the traits of God. They believe that God will give them their sustenance. Imam Sadegh has told:" Little achievement accompanying with a deep belief is more accepted by God than a lot of achievements without belief" (Koleini, Volume 2, page:57).

4. Reinforcement of generosity, nobility, compassionate and prosperity: Man likes having pleasure and likes to be loved. He enjoys his nobility and honor and most of his endeavors are related to these instinct ( Esmaeeli Yazdi, 2005, Page: 118).

5. Magnanimity: Holy prophet of Islam has invited all the people to have generosity of spirit and educated them to be noble and have intellectuality. This issue is so important that God has stated in Holly Quran that the honor of believers is of importance of honor of God and Holy prophet (Heidari Naraghi, 2004, Page:242-243).

6. Being moderate in living: Imam Ali has stated:" Either in secret or in the public be sincere and fearful of God, whether you are rich or poor, be moderate and whether you are happy or angry, behave fairly.(Rassoli Mahallati, 2004, Volume 2. Page:232) Some parents afford to prepare a comfortable life for their family but they are greedy and don't provide them what is necessary for them and make some difficulties for their families (Heidari Naraghi, 2004, Page:233).

7. Considering people with low income and accompanying the poor and helping them: When a person behaves friendly to the poor and have relationship with them and be familiar with their problems, he will learn to be satisfied and avoids being greedy.

8. Visiting graveyards: Moslems go to graveyards to understand that death is a happening that may occur for everybody and he himself will die someday. So he will prepare himself for that day and for being assessed in that day. He will be more careful about others' right.

9. Relying on God: Those who rely on God are not afraid of the future or past. Someone has asked Imam Sadegh: "what is the extent of relying?" Imam has answered:" It is to be certain." That person asked:" What is the extent of certainty?" Imam answered:" It means a state that because of God you are not afraid of anyone" (Koleini, Volume 2, page:57).

10. Asceticism: Imam Ali has stated:" A person who thinks about the other world, will not be interested in the beauties of this transient world. Being uninterested in this world would not decrease the wealth of a person in this world and being greedy and interested in the world would not cause it to be much more ; so those who lose he benefits of the other world are failures" ( Naraghi, 2004, Page:324).

11. Contentment: The opposite of greed is contentment and it means that a person is satisfied with what he requires and not trying to obtain excess money and it is one of the greatest traits of a person. All the virtues are related to this and the comfort of this world and the other world are related to this trait ( Naraghi, 2004, Page:351).

12. Khums and zakat: Khums is fifth one. It is of the types of taxes that Shi'ites believe that in order to solve financial problems of the Muslims and the equitable distribution of health. Zakat is a part of a Muslim's wealth which is given to the poor. It is stated in Holy Quran: "One-fifth of whatever you obtain belongs to God, holy prophet, prophets' relatives, orphans and the poor"( Al Anfal, 41). "Get zakat of their wealth to purify it and help it grow" (Attobe,103). 
13. Helping the poor: Dedicating money to the poor causes the poor to have a better life. Muslims are advised to so.

14. Liking others: Holy prophet has stated that:" The best thing after believing in God is philanthropy and behaving others kindly whether they are good people or sinister ( Mostadrakolvasael, Volume2, page 67, speeches of Heidari Naraghi).

15. Investigating history: When a person studies the history, he thinks about what the people of the past have done, what their destiny was, what has been good and what has been bad and do what the good have done and avoid what the bad have done, this causes them to behave good and have good deed. Imam Sadegh has stated :" taking lessons of others has three benefits. 1. Learning what should be done,2. Doing what is learnt, and 3. Knowing what was not known" ( Vaseghi Raad, 2003, p:122).

16. Generosity and devotion: Imam Ali has told:" Those who are generous are great people"(Rassoli Mahallati, 2004, Volume 2. Page:614). A person who devotes, gives others what he himself needs it.

17. Choosing a good person as a pattern in the life and imitating them: The best persons to imitate are the holy prophet and his wife who were not greedy and devoted their wealth for Islam. Imams have been like the prophet and they have devoted all or half of a part of their wealth for Islam's sake.

In divine religions there is a limited extent for quests and abilities everyone knows the other world is more valuable than this transient world and every rational person perceives that the other world and the human are precious and he shouldn't purchase this world with the other world. The laws of the religion are to teach people the way to prosperity, and tell them to use this world to reach happiness in the other world. Every person will die someday so he should provide himself with what is needed in this world; but it should be considered that there is a difference between trying hard and requesting so much. Imam Ali was one of the people who had made wealth but he had lived a simple life.

Everybody should have a life with contentment although greed is something instinctive and it is located in human to activate him and keep him safe from being inactive and falling (Tehrani, 2013). It should be mentioned that if a person is able to gain more in a correct way, he shouldn't stop it and should use it to help the poor to have a better condition in the other world just like what Imam Ali did and had endowed for pious purposes. "In curing physical illnesses, at first the reason should be recognized and then the medicine should be used to cure it; in illnesses of soul the same procedure should be taken"( Amin, 2007,page:100). Based on what was mentioned and what Imam Ali has said the best cure for greed is contentment. Imam Ali has stated "If a person controls the greed and is satisfied with what he has he will have a perfect religion” ( Vaseti Leithi, Page: 374).

This transient world is one of the creatures of God and is very systematic and very beautiful, so why people are warned not to get absorbed in it? According to Quran verses the problem is in the perception of human from the world. The problem is the fact that some people think that this world is the final point and the do their best to enjoy this world" ( Shirvani, 209, Pages:111-112).

\section{Conclusion}

Since greed causes man to save more than he needs and not to be satisfied, it will mislead man and causes a lot of problems. This instinct not only will become a bad trait but also will be changed into a big disaster. So greed should be trained and be controlled by contentment and generosity which are its opposites.

\section{References}

Amid, H. (1951). Amid Dictionary, Iran: Teharan: Amirkabir Press.

Amin, N. B. (2007). The way to happiness (Ravesh-e Khoshbakhti), Iran: Isfahan: Gonbadhaye Firoozeyee.

Dashti, M. Anthology of Speech (Nahj-al-Balaghe), Iran: Qum: Cultural research institute of Amir Almo'menin.

Dehkhoda, Ali Akbar(1958) Dehkhoda's Dictionary(Loghatnameye Dehkhoda)Iran:Tahran

Delshad Tehrani,Mostafa(2008)A Review of Islamic Education(Seiri dar tarbiyat Eslami)Iran: Qum:Zekr Press

Esmaeeli Yazdi,Abbaas: ( 2005). Ethics culture(Farhan-e- Akhlagh).Iran:Qum: Jamkaran mosque press

Goharin Seyyed Sadegh.(1988)The Explanation of Gnosticism Idioms, First Edition(1988)Iran: Tehran Golshan Press Holy Quran

Hosseini Tehrani,Mohammad Hossein:(2009).Shining Sun(Mehre Tabaan).Iran:Mashhad:Allame Tabatabayee Press

Heidari Naraghi,Ali Mohammad( 2004)Imam Sajjadd's essay of law(Resaaley-e- Hoghooghe Imam Sajjad)

Kardan,Ali Mohammad,et al.( 2010) The Philosophy of Education( Falsafeye Ta'lim va Tarbiyat),Iran:Qum,SAMT Press

Khomeini,Roohollah(1992)(Sahifeye Noor).Iran:Tehrn:Imam Khmeini's works Press

Khomeini,Roohollah(2008)Forty Traditions (Chehel Hadith).Iran:Tehrn:Imam Khmeini's works Press

Koleini,Mohammad Ebne Ya'ghoob(....) Alkafi, Iran:Tehran:Osveh Press Mah 
Makarem Shirazi,Naser.( 2006),Ganjineye Ma;arefe Eslami

Motahhari,Morteza.( 1980)Instinct( Fetrat) Iran: Tehran: Sadra Press

Moosavi Lari, Mojtaba(2012)Greed,USA:Washington Islamic Education

Naraghi,Molla Ahmad(2004)

Ragheb Isfahani,Aboulghasem Hossein Ebn-e- Mohammad(1971)(Mo'jam Mofradate Alfazel Ghor'an

Rassoli Mahallati,Hashem(2004)(Ghorarol Hekam va Dorarolkelam)Iran: Tahran:Farhange Eslami Press

Reyshahri,Mohammad. (1982), Mizanol Hekmah,Iran: Qum:Tablighat Eslami Press

Sajjadi, Ja'far(1996) The Dictionary of Gnosticism Idioms(Farhange Estelahat va Ta'birate Erfani),First Edition,Iran:Tehran: Golshan Press

Shirvani,Ali(2009) IslamicEthics and its theoretical basis(Akhlagh-e- Eslami va Mabani-e- nazari)Iran:Tehran:Andisheye Moulana Press

Shoja'ee,Mohammad Sadegh(2007) Mesbah Yazdi's psychologicalmpoints of view(Didgahhaye Ravan shenakhtie Mesbah Yazdi),Iran;Qum:Imam Khomeini Educational Institute

Tabatabayee,Mohammad Hossien(1984) Tafsir-e- Almizan, Allame Tabatabayee Institute

Teharani, Mojtaba(2013).Essays of worship(Rasael-e-bandegi).Iran:Tehran:Masabiholhoda

Vaseghi Raad,Mohammd Hossein(2002).Islamic Ethics and Education

Vaseti Leithi,Mohammad Ebne Ali(Uyoonol Hekam vaAlmavaez)

Ya'ghoobi,Abolghasem(2009),Social Warnings.Iran:Qum: Paasdare Slam Press

Zarneghar, A., \&Valaazadeh,A.,(2012) 